\title{
Rickets and the Fairfax family receipt books
}

\author{
Layinka M Swinburne
}

J R Soc Med 2006;99:391-395

Domestic receipt books can add another dimension to the history of medicine. The Reverend Henry Fairfax, rector of Bolton Percy near Tadcaster, took over the receipt book, which his wife, Mary Cholmeley, brought with her on their marriage in 1626. He added to the original collection of culinary and medicinal receipts and compiled an index. The manuscript had been passed from one generation to another and covers a span from the early 17 th to late 18 th centuries. It was rescued from destruction by George Weddell, who published a facsimile in 1890 as Arcana Fairfaxiana Manuscripta. The majority of the remedies in these MSS were gleaned or copied from unknown sources but relatives and friends contributed many others. Some were attributed to well-known doctors who had attended them personally such as Sir Theodore Turquet de Mayerne, Dr Butler and Dr Matthew Lister.

Amongst the remedies for such common conditions as bleeding, agues, and the stone, there are several in Henry's handwriting labelled 'for the Ricketts'. Alongside the heading of another remedy 'For a child that is weak or lame in her joynts' Henry added a note 'For the Ricketts' (p 167). Of special significance is a page dated 25 February 1632 containing a group of five remedies 'For the Ricketts (in children)' contributed by Lady Fairfax of Steeton, his cousin's wife. Documents confirm that he might indeed have visited Lady Fairfax at nearby Steeton on that date on his return from a journey to London ${ }^{1}(\mathrm{p} x \mathrm{x})$. Her remedies include a herbal syrup, an ointment with which to anoint the back, sides and hams with the instruction 'and after rowle and tumble it', and a herbal decoction to apply to the navel. In addition, there was an elaborate water to be mixed with the syrup for rich folks, starting with a broth of spitroasted sucking pig, St Christopher's herb (Osmunda regalis), almonds, figs, raisins, and garden snails distilled with several herbs. Gold leaf, amber and pearls were to be added to the final water. However, if the child was far spent, 'for the poorest sort' a drink of garden snails in sugar and water three times a week would suffice.

Lady Selby, Henry's niece, contributed further remedies from her mother-in-law, Lady Sheffield's book: a drink of boiled currants in wine vinegar and a complicated cock

16 Foxhill Crescent, Leeds LS16 5PD, UK

E-mail: layinka.s@dsl.pipex.com broth with hart's tongue, liverwort and other herbs with which the back and joints were to be anointed ${ }^{1}$ (p 171). An identical remedy labelled 'For the German Evill' occurs in the manuscript receipt book belonging to Dame Mary Lister of Thornton in Craven. She was related to Henry Fairfax through her son's marriage to the daughter of Lady Fairfax of Steeton. She was also related to the prominent physician Dr Matthew Lister and two of his receipts are included in her book. The manuscript covers the years 1626-1635 and there are several dated kitchen inventories before and after the receipt, which must have been written between 1629 and 1630. The manuscript contains other remedies 'from Lady Fairfax'.

Three very similar remedies occur in the manuscript Lady Fairfax Booke of Receipts belonging to another member of the family. This Lady Fairfax was Anne Vere, wife of General Sir Thomas Fairfax, and daughter of Sir Horace Vere of Tilbury. The regime includes a drink, a purge, and an ointment.

\section{f 95 An Oyntment for $y^{\mathrm{e}}$ Ricketts}

Camomile, Coltsfoot, Pennyroyal, ffeatherfew. \& Alehoofe alias Tunshoofe of each alike minced and with as much sweete butter mingled and boyled gently 3 Houres and then streined and put into it some large Mace \& so keep it in a Gally pott glass.

\section{A Drinke for $\mathbf{y}^{\mathrm{e}}$ Ricketts}

Liverwort, Ceterach, Hart's tongue, Mayden haire \& Soulwort alias Wallrewe and a quarter of Osmund roote and an ounce of Licoras and a little Aniseed to be boyled in water with $\mathrm{y}^{\mathrm{e}}$ Malt soe mashed up as to make ale to be drunk after 4 days.

\section{f 125 To cure the Ricketts}

$\mathrm{R}$ Raisins of $\mathrm{y}^{\mathrm{e}}$ sunne stoned \& Currants of each one handfull. Maydin haire, Yarrow \& Speedwell of each a handfull, halfe a handful of Dragon Leafe or for the want of a Spoonfull of water stilled in a Cold Still, a good handfull of Liverwort, Leaves of Hartstongue. 1 Spoonful of Aniseeds \& 1 ounce of Licoras.

Boyle all these in a pottle of Ale till it come to a Quart. Then strayne it and put it into little bottles \& soe let the Child drinke thereof a Draught in the Morninge \& fasting about an houre after meales. 
Anne Vere married Thomas Fairfax, a nephew of Henry Fairfax, in 1637. A single remedy dated 1640, 'for the stone' from her sister-in-law Lady Stapleton occurs in the same section of the manuscript. Local names of plants such as 'harith'(cleavers), 'soulwort' (wall rue) and 'hey haze' (not identified) occur alongside more sophisticated ingredients. The addition of gold, pearls and amber in one of the Arcana receipts was fashionable in medical practice. However, it is notable that in none of them is a physician quoted as source but the remedies were clearly in circulation amongst family members. In contrast by the end of the 17th century in domestic manuscript receipt books remedies for rickets are frequently copied from Glisson's treatise, or attributed to contemporaneous local doctors.

\section{RICKETS-A NEW DISEASE}

\section{Indications of popular knowledge}

The first printed reference to rickets occurs as a cause of death in the London Bills of Mortality in 1634 quoted by Fuller in 1670 . He claimed that it was an absolutely new disease. Sir John Floyer thought that although it seemed a new disease, it might have been a condition described by Hippocrates. He wrote:

'In the time of King Charles I it was almost epidemical, few families escaping it, especially those that were rich and opulent and put their children out to nurse'.

By the 1640s it was prevalent in England. Arnold Boate, a Friesian physician working in Ireland, commented in his description of Ireland published in 1645 that it was so well known as to need no description.

Daniel Whistler having spent the preceding 2 years in Holland as a medical student wrote his MD dissertation at Leyden University on the disease, which was popularly known as the rickets. In 1646 a group of eight doctors under the aegis of the Royal College of Physicians set out to report on the condition, which was said to be prevalent in the West Country. In the end the five involved in writing the account left the task to Francis Glisson who produced his classical description De Rachitide published in Latin in 1650. It included a description of symptoms and appearances with post mortem findings, conjectures about the causes, and a systematic regime including diet drinks, spinal ointments and physical treatment very similar to the Fairfax battery. Glisson included neither sources for his information or nor provenance for the suggested treatment. He made no reference to Whistler's dissertation. An English translation was published in 1651. From then on, having acquired the respectability of a Latin name, the authors refer to Glisson's masterpiece. Robert Pennel (1653) in his Treatise on the Diseases of Children wrote:

'concerning the Rickets, there is a learned Treatise set forth lately by three or four doctors, and since translated into English, where you have that disease accurately and exactly handled unto which I refer the Reader'.

Its renown was such that on the continent the condition became known as Glisson's disease or the English disease.

Nicholas Culpeper's translation of the London Pharmacopoeia (1653) includes not merely the Materia Medica and formulae but his own (often vitriolic) comments on the College and, more interestingly, hints on the use of the materials. He describes several remedies as 'excellent good' for 'the disease in children which women call the Ricketts' and jeered at the College's adoption of the Latin term.

The Fairfax family remedies were written 15-20 years before Glisson's account. Typical examples are that of Anne Fairfax above. They are no different in character from many official prescriptions of the day and are very similar to those offered by Glisson and later medical writers. Guthrie described the two remedies included in the Lady Sedley's receipt book of 1686 as 'but gleanings from Glisson', but they are mixed brews with currants, raisins, ferns and other herbs similar to the Fairfax collection. Osmunda regalis root, maidenhair fern, and wall rue figure frequently. Fuller claimed that Osmunda was almost a specific for the disease and it continued as a folk remedy in Ireland until recently. Wall rue was commonly known as tentwort in the 19th century from its use in treating 'the taint' as rickets was sometimes known. There was a suspicion among families and doctors that a bad wet-nurse or poor feeding provoked the condition although the concept of nutritional deficiency had to wait until the beginnings of nutritional science in the 19th century. Floyer claimed that there was a Welsh saying 'no child has the rickets but he has a dirty slut for his nurse'6 (p 94).

Drummond and Wilbraham speculate on possible links between medicine in England and the Netherlands, where so many physicians studied and graduated (p 152-5). In particular, they refer to Dr Arnold Boate and his brother Gerard, graduates of Leyden University and sons of a Friesian physician who had settled in London. Arnold moved to Ireland as physician to Robert Sydney and was Physician General to the English forces during the Civil War. He set up practice in Dublin. He included a description of rickets in his account of disease unknown to the ancients as Tabes pectorea. He mentioned its common occurrence in both England and Ireland.

From the time of Elizabeth I's support of the Dutch in their fight for independence from Spain, many English families spent time in the Lowlands as soldiers, diplomats, 
and their supporters. The Netherlands was the natural refuge for English Protestants. Several members of the Fairfax family had strong connections with the Netherlands extending over three generations. Thomas Fairfax had been sent out to the Brill, one of the customary ports under English governorship, in 1628 to serve under Sir Horace Vere. Both his father, Ferdinando, and grandfather, Sir Thomas Fairfax of Denton, had spent long periods in the Netherlands. The remedy for weak children, which Henry annotated as 'for the rickets', was taken from Lady Sheffield's book. Her father, Sir Edmund Sheffield had been Governor of the Brill in 1699. Sir Horace Vere, Lady Fairfax's father was appointed Governor of the Brill, in succession to his brother Sir Francis Vere. Anne had been brought up in the Netherlands and her two older sisters were naturalized by Act of Parliament on the family's return to England in 1624. Sir Edward Conway, who gave Anne Fairfax her receipt book, was brought up in the Vere household in the Brill and his father Sir Edward Conway, had been a former Governor of Ostend. Cousins of Dame Mary Lister had emigrated to Leyden

\section{St Willibrord}

Near the southern border of the Netherlands lies 'sHertogenbosch or Bois-le-Duc, scene of a famous siege in 1629 in which young Thomas Fairfax took part. A visitation under the auspices of the Bishop of 's-Hertogenbosch in 1614 records pilgrimage linked to the Abbey of Baseldonk The monastery was noted for the treatment of children suffering from St Willibrord's infirmity, 'het gebreck van Sint Willebrort' using water from a well in the vicinity dedicated to St Willibrord. The symptoms of the condition were described as follows:

'The children get little knobs on their ribs like pin heads or rosary beads or of similar size.'

This is a typical manifestation of rickets. According to the report children were given the water to drink in amounts ordered by the priest on three successive Fridays. Cold bathing is not mentioned but was customary at other holy springs dedicated to the saint. St Willibrord was born in Northumberland in 685 of highly religious parents. His father decided to withdraw to Spurn Point to live as a hermit and young Willibrord was left in the care of the monks at Ripon Abbey under St Wilfred. After becoming a Benedictine monk he spent 12 years in Ireland and eventually went to Friesland to promote Christianity. He became Bishop of Utrecht and is patron Saint of the Netherlands. He is noted for the miraculous discovery of a spring by striking the ground with his staff and a number of wells were dedicated to him and attracted pilgrims. He is depicted with an abbey in one hand and the staff in the other standing by a large container of water.

The description in the visitation of 1614 suggests that rickets was prevalent in the Netherlands at a time the English military governors and their families were in residence. They may well have met local expertise in the condition, including resort to Holy springs such as St Willibrord's. The Dutch reputation endured. In 1640 young Ralph Verney was sent to Utrecht to have his legs straightened. The grandchildren of Lady Anne Clifford were sent to Utrecht in 1655 for the treatment of rickets and returned two years later in a man-of-war. On their return they were taken off to St Mungo's well, near Knaresborough for further treatment by cold bathing.

Alice Thornton of Newton consulted Dr Wittie of York who treated rickets and convulsions in her daughter by all means possible, which included taking her to St Mungo's well.

James Deane (1626) mentioned St Mungo's well in his Spadacrene Anglica and commented that its only virtue had been the simplicity and purity of the water. 'Two whereof have gotten and purchased that reputation to be saincted: The one called by the name of Saint Magnus, or MagnusWell: The other that of St Robert.' 'People of the common sort, especially the female sexe' flocked to the wells for a year or two but 'Time hath quite worne all their strength, and consumed all their vertues so that nothing of worth now remains saving onely their bare names and titles'. Interest had shifted to springs with a high mineral chemical content. Sir John Floyer noted that the well had a reputation for the treatment of ailments of women and children earlier in the century and had fallen into desuetude but had been revived for the treatment of rickets. (He did not claim that this was a direct revival of earlier use for this condition.) He himself sought out a spring with the appropriate qualities and sent his patients to St Winifred's well near Lichfield ${ }^{6}$ (p 5).

\section{DISCUSSION}

The Bills of Mortality show that the term 'rickets' was well known to the London searchers by 1634 . The absence of printed references using the word prior to this is remarkable but the manuscript records of the Fairfax family are evidence of familiarity with rickets and a package of measures for its treatment by 1632. Dame Mary Lister's name 'the German Evill' is a pointer to a source of this knowledge. The remedy in the Arcana for a child that is weak or lame in her joints, amended by Henry Fairfax to 'Rickets', shows his increasing confidence in the label.

Both Whistler and Culpeper stress the unofficial nature of the popular name of the condition. 
The London physicians believed that it had originated in the West Country. However, it was also familiar to this group of Northern families. A similar remedy occurs in a manuscript from another region where there is a contribution dated 1638 from the Lady Cornwallis, members of whose family also had its share of expatriation in the Netherlands. Her remedy consisted of ash and ivy bark brewed in ale. With a few additions it turns up in Thomas Fuller's Pharmacopoeia Extemporanea of 1710. Lady Winn of Nostell Priory acquired the same recipe about this time from a Mrs Froude and in place of the usual probatum est she added 'is of no use'.

\section{The rickety rosary and the Netherlands connection}

Domestic manuscripts lack any hint of diagnostic criteria but the comparison of costal rickets to a rosary shows that in gross form the disease is distinctive enough to have been suspected by anxious parents even if doctors were disparaging in their references to the popular name. Whistler and Glisson may have acquired the simile from the Netherlands usage. It is probable that not only doctors, as Drummond and Wilbraham suggested, but also lay members of the Fairfax and Vere families with a particularly strong association, gained their familiarity with the treatment of rickets during their residence in the Netherlands the early 17 th century.

Remedies were suggested for both rich and poor children. There is no direct evidence that the numerous children of the Fairfax family group suffered from rickets although it occurred in children of neighbouring wealthy families such as the Cliffords and possibly a child of their relative the Duke of Bedford.

Several members of the Fairfax family had lengthy connections with the Netherlands but there are no obvious culinary or medical gleanings of Netherlands origin in their manuscripts. Lady Fairfax's battery of remedies of 1632 suggests a system of treatment already in common use. The materia medica is not distinctive although later 17th century recipes often include Tamarisk, more commonly used in Germany and Netherlands than in Britain. No manuscript remedies for rickets are attributed to medical authorities until after the publication of Glisson's treatise. The origin of his remedies remains just as recondite but this work then became, directly or indirectly, the main authority. By the last decades of the century manuscripts of northern families quote both local doctors and printed sources.

17 th century medicine relied on written precedent, the more ancient the better. Johan van Beverwijck a physician of Dordrecht, Netherlands, published popular works on health and medicine, which are still available today. He did not mention rickets, in contrast to his inclusion of a long chapter on scurvy and its treatment, relying on the work of the 16th century physician Piet Foreest, and his rapid adoption of Harvey's theory of the circulation of the blood soon after its publication. Both Foreest and van Beverwijck stressed the importance of not allowing small children to walk too soon because their bones were soft.

A brief description of rickets in 1614 was associated with pilgrimages to a spring dedicated to St Willibrord in 's-Hertogenbosch. The first published descriptions of the condition were those of the Friesian physician Arnold Boate, and Daniel Whistler in Leyden. The reputation of Dutch doctors in treating rickets attracted children of several wealthy English families later in the century.

It is probable that not only doctors, as Drummond and Wilbraham suggested, but also lay members of the Fairfax family gained their familiarity with the treatment of rickets during residence in the Netherlands in the early 17th century. Further evidence might be found through a comparison with manuscripts from other regions, but survivals from the period before and during the civil war are comparatively scanty.

Reasons put forward for the increased incidence of rickets in the 17th century have included a prolonged climatic down turn with wet summers and hard winters. In wealthy families it became fashionable to employ wetnurses in place of maternal breast-feeding which became almost the exception. There was a suspicion among families and doctors that a bad wet-nurse or poor feeding provoked the condition although the concept of nutritional deficiency had to wait until the beginnings of nutritional science in the 19th century. Sir John Floyer claimed that 'no child has the rickets unless he has a dirty slut for a nurse' 6 (p 94). Non-dairy paps for weanlings aggravated the marginal intake of calcium salts whilst elaborate clothes of wealthy children must also have diminished skin exposure to sunlight.

Receipt books of the 18 th century continued to include remedies for rickets. None of the measures advised could be expected to have the slightest effect on a rickety child: but the use of diet drinks, ointments, purges, and shaking were perpetuated, as typified by the recommendations in the first edition of Encyclopaedia Britannica 1768. The benefits of cod liver oil and later, sunlight, in curing rickets were shown during the 19th century long before the concept of dietary deficiency began to emerge $\mathrm{e}^{16}$ (p 149). The discovery of accessory food factors by Sir Frederick Gowland Hopkins in 1906 was followed by Sir Edward Mellanby's experimental production of rickets in 1918, which produced convincing evidence of the part played by a factor later named vitamin D.

Rickets is resurgent worldwide. It is to be hoped that awareness of the condition among doctors will be more acute than in the past. 


\section{Competing interests None declared.}

Note A preliminary version of this work was presented in February 2004 under the title 'My little Lord's legs' at an international conference on Recipes in Early Medicine: The Production of Medicine, Food, and Knowledge, hosted by the Wellcome Unit for the History of Medicine, in Oxford.

\section{REFERENCES}

1 Weddell G. Arcana Fairfaxiana Manuscripta. Newcastle upon Tyne: Mawson, Swan \& Morgan, 1891

2 Dame Mary Lister of Thornton-in-Craven. My Receipt Book, MS 621. Leeds: Leeds University Library Special Collections

3 Lady Fairfax Booke of Receipts, MS 118. By kind permission of the Master and Fellows, Sidney Sussex College, Cambridge

4 Savile Papers, DD148. Yorkshire: Yorkshire Archaeological Society, 1683

5 Fuller T. Pharmacopoeia extemporanea. London: B Walford, 1710

6 Floyer Sir John Baynard E. Psychrolousia: Or The History Of Cold Bathing, Both Ancient And Modern. In Two Parts, 3rd edn with additions. London: printed by JB for Benj Walford, 1709

7 Whistler D. De morbo puerili Anglorum, quem patrio idiomate indiginae vocant The Rickets. Leyden, 1645

8 Glisson F. De Rachitide, sive Morbo Puerili, qui vulgo The Rickets dicitur London: 1650

9 Culpeper N. A Treatise Of The Rickets: Being A Disease Common To Children. London: Peter Cole, 1651

10 Pennell Robert. De Morbis Puerorum, or a Treatise of the Diseases of Children, Ch XIV. London: J Legass, 1653

11 Culpeper N. Pharmacopoeia Londinensis or the London Dispensatory. London: Peter Cole, 1653

12 Guthrie LG. The Lady Sedley: her receipt book, 1686, and other seventeenth-century receipt books. Proc Roy Soc Med. 1913;6:150-69
13 Allen D Hatfield G. Medicinal Plants in Folk Tradition: An Ethnobotany of Britain and Ireland. Portland: Timber Press, 2004

14 Fernie WT. Herbal Simples, 3rd edn. Bristol: John Wright \& Sons Ltd, 1914:176

15 Rajakumar K. Vitamin D, Cod-Liver Oil, Sunlight, and Rickets: A Historical Perspective. Pediatrics 2003;112:e132-5

16 Drummond JC, Wilbraham A. The Englishman's food, revised edn. London: Jonathan Cape, 1958:152-5

17 Drummond JC, Wilbraham A. Observationes medicae de affectibus a veteribus omissis. Dictionary of National Biography, report of 1917 edn. Oxford: OUP, 1960:154 1649:156

18 Markham CR. Life of the Great General Thomas Fairfax. London: MacMillan, 1870:24

19 [www.sintwillibrordus.nl/gesch-willibrord.htm]

20 Verney Lady Frances Parthenope. Memoirs of the Verney Family during the Civil War. London: Longmans, Green, 1892

21 Clifford Anne. In: Clifford DJH, ed. The Diaries of Lady Anne Clifford. Stroud: Alan Sutton, 1990

22 Thornton Alice. In: Jackson C, ed. The Autobiography of Mrs. Alice Thornton of East Newton. Surtees Soc 1873;62:94

23 Deane, James. Spadacrene Anglica or the English Spa Fountain.1626, reprint, with introduction by James Rutherford. London: John Wright \& Sons, 1921

24 Benjamin Hayes, MS.12. Leeds: Thackray Museum Resource Centre, 1647

25 Nostell Priory. C4/8/1 My Recipe Book. Leeds: West Yorkshire Archive Service, 1718

26 Scott Thompson, Gladys. Life In A Noble Household. London: Jonathan Cape, 1938:65

27 Beverwijk Johan van. De Schat der Gezondheid, vol. 1, Alle de Wercken. First published 1636. Amsterdam: Jan Jacobsz Schipper, 1664

28 Wharton B, Bishop N. Rickets. Lancet 2003;362:1389-400 